\title{
TIPOLOGI TANDA DALAM BALAMUT LAKON DAN PEMAKNAANNYA
}

\author{
Sainul Hermawan ${ }^{1}$
1. FKIP Universitas Lambung Mangkurat Banjarmasin, Kalimantan Selatan sainulh2010@gmail.com (081348905090)

\begin{abstract}
ABSTRAK
Upaya memanggungkan kisah Lamut dari tradisi lisan balamut di Kalimantan Selatan telah dilakukan sejak 1997. Namun baru pada 2014 upaya itu dapat didokumentasikan. Dokumentasi teaterikalisasi cerita Lamut memungkinkan kajian ini, yaitu tentang tipologi tanda dalam teater. Artikel ini ingin menunjukkan bahwa kisah Lamut dalam tradisi lisannya bukan teater, dan ingin menjelajahi bahwa mendekati dan memaknai pertunjukan teater dengan semiotika berbeda dengan mendekati naskah drama atau karya sastra pada umumnya. Semiotika teks tulisan dan teks lisan berbeda dari semiotika pertunjukan. Dengan memandang semua unsur pertunjukan di atas panggung sebagai tanda, signifikasi teatrikal tidak dapat direduksi menjadi relasi searah antara sarana-sarana tanda tunggal dan makna individualnya. Pertunjukan teater membawa faktor-faktor komunikasi yang berlapis-lapis yang berimplikasi pada kemungkinan terciptanya bermacam-macam pesan. Artikel ini akan menganalisis pertunjukan teater Balamut Lakon episode Bujang Maluala karya sutradara Rudi Karno (2014) dengan pendekatan semiotika teater untuk memahami dialog antara budaya Banjar dan budaya lain, dan antara cerita Lamut di atas panggung teater dan cerita Lamut dalam tradisi lisannya.
\end{abstract}

Kata Kunci: semiotika, teater, komunikasi, kritik teater, budaya Banjar, dan dialog budaya.

\section{PENDAHULUAN}

Tradisi lisan balamut merupakan pertunjukan tradisi menuturkan cerita tentang riwayat raja-raja dari Kerajaan Palinggam Cahaya. Cerita dituturkan seorang diri oleh penutur cerita yang dalam bahasa Banjar disebut palamutan. Cerita dituturkan dalam bahasa Banjar dengan iringan musik rebana atau tarbang lamut yang dimainkan sendiri oleh si palamutan. Tradisi ini disebut balamut karena di dalam cerita yang dikisahkan ada tokoh Lamut, nama panglima paling sakti di kerajaan Palinggam. Ia bukan tokoh utama, tetapi jelmaan Dewa Batara Wedi yang oleh sebagian orang Banjar dimitoskan sebagai "orang gaib" yang bisa dimintai pertolongan.

Jarkasi dkk. (1997: 5) menyebut lamut sebagai sastra lisan dan sekaligus teater tutur. Pengkategorian ini mempengaruhi beberapa penulis berikutnya. Muhammad dan Bakhtiar (2000: 58) juga menggolongkan lamut ke dalam teater tutur. Mereka memandang palamutan atau penutur lamut sebagai sutradara dan sekaligus aktor yang menciptakan karakter dinamis pada tokoh cerita yang sudah baku. Definisi ini diikuti juga oleh Syarifuddin dkk (2008: 22). Akan tetapi, pada bagian lain, Syarifuddin dkk juga menyebut lamut sebagai bentuk pergelaran 
sastra lisan yang di dalamnya terdapat bentuk sastra yang lainnya, yaitu pantun, syair, dan prosa lirik (Syarifuddin, dkk, 2008: 26). Sedangkan Mukhlis (2004) menyebutnya sebagai kesusastraan tutur. ${ }^{1}$

Yusran dkk. (2004: 17-18), dalam buku Peta Kesenian Kalimantan Selatan, menggolongkan lamut sebagai karya seni sastra lisan. Pengategorian Yusran dkk. (2009: 16-24) berbeda dengan kategori lamut dalam buku saku Sekilas tentang Seni Tradisi Kalimantan Selatan terbitan Dinas Pemuda, Olahraga, Kebudayaan, dan Pariwisata, UPTD Taman Budaya, Provinsi Kalimantan Selatan. Dalam buku ini lamut diletakkan dalam bab yang membahas tentang seni teater. Kemudian, Sabhan (2011) menjelaskan bahwa lamut merupakan salah satu bentuk sastra lisan atau seni pertunjukan. Sabhan juga mengutip definisi lamut dari buku terbitan Depdikbud (1994:2) yang menyatakan bahwa lamut merupakan seni mengucapkan syair dengan berlagu yang diiringi alat musik. Secara konsisten Sabhan kemudian lebih banyak menyebut lamut sebagai seni pertunjukan.

Perbedaan kategori lamut menunjukkan, pertama, masih dominannya penggunaan kategori sastra modern yang belum mewadahi kompleksitas lamut sebagai sebuah genre. Kedua, lamut cenderung dilihat sebagai sastra lisan sehingga analisis penelitian terdahulu cenderung mengarah pada transkripsi cerita. Penjelasan mengenai bagaimana, kapan, dimana, dan dalam tujuan apa transkripsi tersebut diperoleh tidak dijelaskan. Jika teks transkripsi penelitian terdahulu dibandingkan dengan salah satu rekaman tuturan yang ada, tampak bahwa transkripsi tersebut diperoleh dari dua kemungkinan: pertama, palamutan diminta untuk menulis garis besar seluruh cerita yang biasa dilisankannya mulai dari awal sampai akhir. Kedua, para peneliti merekam garis besar cerita dalam situasi wawancara. Hasilnya, penelitian terdahulu mengabaikan dinamika balamut dalam konteks yang otentik: dalam rangka pertunjukan biasa atau dalam rangka ritual.

Untuk konsistensi pembahasan, dalam artikel ini, penggunaan istilah lamut, balamut, dan teater lamut/balamut merujuk pada pengertian yang berbeda, yakni lamut merujuk pada cerita lamut sebagai sastra lisan (sebagai teks atau transkripsi cerita Lamut); balamut merujuk pada kegiatan menutur cerita Lamut oleh palamutan, baik untuk hiburan, hajatan, maupun pengobatan; teater lamut/balamut merujuk pada pemanggungan tradisi balamut sebagai karya kolektif. Teater balamut oleh para pelakunya disebut juga balamut lakon.

Pergelaran balamut lakon karya Sutradara Rudi Karno, 25 April 2014, yang bersandar pada kisah Lamut versi Gusti M. Jamhar Akbar, dengan durasi sekitar 2 jam, bukanlah satu-satunya upaya seniman teater memanggungkan tradisi lisan balamut ke pentas teater. Mendiang Bakhtiar Sanderta pernah mengangkat cerita Lamut ke pentas teater dalam Festival Pertunjukan Sastra Nusantara di Taman Budaya Nusa Tenggara Barat, Mataram pada tahun 2007. Lakon berjudul "Sunduk Winata" yang berdurasi 15 menit itu menampilkan Y. S. Agus Suseno sebagai pemeran tokoh Lamut. Namun, sepuluh tahun sebelumnya, ternyata

\footnotetext{
${ }^{1}$ Meskipun sejak 1997 lamut telah disebut-sebut sebagai teater tutur, kesenian ini tidak dicatat sebagai bentuk seni pertunjukan Kalimantan dalam Direktori Seni Pertunjukan Tradisional (Anonim, 1999: 51-58). Ada 43 seni pertunjukan Kalimantan dalam buku ini dan semuanya lebih banyak berupa tari dari suku Dayak. Satu-satunya teater tradisi yang masuk dalam direktori ini adalah mamanda.
} 
Akhmad Riady telah mementaskan episode Bujang Maluala versi palamutan Gusti Mas'udin dengan lakon berjudul ""Bayang di Cermin Titian Nasib" dengan durasi 25-30 menit di Taman Budaya Kalsel pada 1997. Amur tampil sebagai pemeran Lamut. Pada 1985, Hamzi juga menyutradarai teater yang ide ceritanya dibuat oleh Haboel yang bersumber dari cerita lamut versi palamutan Ilham di Kalimantan Timur. Teater lamutnya berdurasi 30-45 menit, dimainkan oleh 8 pemain dan dipentaskan di beberapa kota di Kalsel dan Sulawesi Tengah.

Artikel ini akan memfokuskan perhatian pada rekaman video pertunjukan teater lamut karya sutradara Rudi Karno (2014) sebagai satu-satunya pertunjukan teater lamut yang dokumentasinya bisa dijangkau. Balamut lakon tersebut mentransformasi episode cerita Bujang Maluala dari tradisi lisan versi M. Jamhar Akbar. Dengan demikian, artikel ini akan membaca sebagian dialog intertekstual antara pertunjukan teater dan tradisi lisan sebagai sebuah model dialog kebudayaan. Analisis akan difokuskan pada tipologi tanda dalam pertunjukan teater balamut.

\section{TEORI DAN METODOLOGI}

Semiotika dapat dikonsepsikan sebagai sebuah kesatuan pendekatan teoretis terhadap beragam sistem penandaan dan komunikasi. Dalam pengertian ini semiotika membentuk wacana metalinguistik yang berhubungan dengan objeknya dengan menggunakan kategori yang homogen. Semiotika juga bisa dikonsepsi sebagai sebuah deskripsi beragam sistem tersebut yang menekankan perbedaan, unsur strukturalnya - dari bahasa verbal ke gestur, dari citra visual ke posisi tubuh, dari bunyi musik sampai fesyen. Semiotika dapat meneliti beragam ranah itu dalam level dasar dari unit-unit pembentuknya (seperti kata, warna, bentuk fisik bunyi, bentuk geometri atau topografi), atau pada level teks yang lebih rumit dan wacana-yakni struktur naratif, gaya bahasa, dan sebagainya (Eco, 1977: 108). Kemudian, bagaimana hubungan antara semiotika teater dan kajian teater? Pertanyaan ini mengingatkan kita pada debat yang terkenal antara Saussure dan Barthes tentang hubungan antara linguistik dan semiologi: apakah linguistik hanya bagian dari ilmu umum ini, yaitu semiologi, yang hukum-hukumnya dapat diterapkan untuk linguistik (Saussure), atau sebaliknya semiologi memodelkan dirinya pada pola umum linguistik (Barthes)? Kajian teater statusnya tidak sama dengan linguistik. Oleh karena itu semiologi teater tidak bisa menggunakan konsep yang ketat dari kajian linguistik.

Semiologi teater adalah disiplin baru-formulasi teoretisnya dapat ditempatkan secara historis - dan disiplin ini diharapkan memiliki tempat dalam spektrum kajian pertunjukan, tanpa mengesampingkan pendekatan lain.

Karena ada beragam seni yang meliputi pengalaman manusia dalam teater, lalu apa objek spesifik dan pijakan awal dari semiotika teater? Tadeusz Kowzan, salah seorang pakar semiotika teater yang terkemuka pada 1970-an (pengarang buku Litearture et spectacle, Mouton, 1975) memilah 13 sistem tanda dalam sebuah karya pertunjukan teater: kata-kata, infleksi suara, mimik wajah, gestur, gerakan tubuh, tata rias wajah (makeup), penutup kepala, kostum, asesoris, desain panggung, pencahayaan, musik, dan suara efek (noise). Setiap sistem ini memiliki logikanya sendiri. 
Tabel 1 Klasifikasi sistem tanda Kowzan

\begin{tabular}{|c|c|c|c|c|c|c|}
\hline $\begin{array}{l}1 \\
2\end{array}$ & $\begin{array}{l}\text { Kata } \\
\text { Nada }\end{array}$ & $\begin{array}{l}\text { Teks } \\
\text { Lisan }\end{array}$ & \multirow{3}{*}{$\stackrel{0}{\tilde{0}}$} & $\begin{array}{l}\text { Tanda } \\
\text { auditif }\end{array}$ & waktu & $\begin{array}{l}\text { Tanda auditif } \\
\text { (aktor) }\end{array}$ \\
\hline $\begin{array}{l}3 \\
4 \\
5\end{array}$ & $\begin{array}{l}\text { Mimik } \\
\text { Isyarat/gestur } \\
\text { Gerakan }\end{array}$ & $\begin{array}{l}\text { Ekspresi } \\
\text { Tubuh }\end{array}$ & & \multirow{3}{*}{ 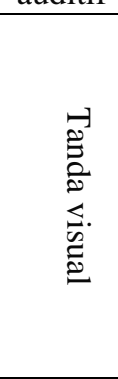 } & $\begin{array}{l}\text { Ruang } \\
\text { dan } \\
\text { waktu }\end{array}$ & \multirow{2}{*}{$\begin{array}{l}\text { Tanda visual } \\
\text { (aktor) }\end{array}$} \\
\hline $\begin{array}{l}6 \\
7 \\
8 \\
\end{array}$ & $\begin{array}{l}\text { Make-up } \\
\text { Gaya rambut } \\
\text { Kostum/pakaian }\end{array}$ & $\begin{array}{c}\text { Tampilan } \\
\text { Eksternal } \\
\text { Aktor }\end{array}$ & & & ruang & \\
\hline $\begin{array}{l}9 \\
10 \\
11 \\
\end{array}$ & $\begin{array}{l}\text { Properti } \\
\text { Latar } \\
\text { Pencahayaan }\end{array}$ & $\begin{array}{l}\text { Tampilan } \\
\text { panggung }\end{array}$ & \multirow{2}{*}{ 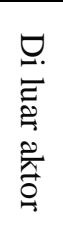 } & & $\begin{array}{l}\text { Ruang } \\
\text { dan } \\
\text { waktu }\end{array}$ & $\begin{array}{l}\text { Tanda visual } \\
\text { (Di luar aktor) }\end{array}$ \\
\hline $\begin{array}{l}12 \\
13\end{array}$ & $\begin{array}{l}\text { Musik } \\
\text { Efek Bunyi/Suara }\end{array}$ & $\begin{array}{c}\text { Bunyi } \\
\text { Non- } \\
\text { artikulasi }\end{array}$ & & $\begin{array}{l}\text { Tanda } \\
\text { auditif }\end{array}$ & waktu & $\begin{array}{l}\text { Tanda auditif } \\
\text { (di luar aktor) }\end{array}$ \\
\hline
\end{tabular}

Klasifikasi sistem tanda Kowzan ini menunjukkan keutamaan aktor bagi ketigabelas sistem yang teridentifikasi. Aktor menjadi tempat bagi terjadinya transmisi tanda-tanda auditif yang terkait dengan teks, dan tempat utama bagi signifikasi visual (Aston dan Savona, 1991:105-106). Dengan menganalisis para pemain sebagai lokus sistem-sistem tanda, berguna untuk menunjukkan bagaimana kesan bisa dicapai. Bagaimana teks yang diucapkan mempengaruhi makna. Pola-pola tekanan, intonasi, volume suara dan sebagainya berkontribusi pada pembacaan yang spesifik. Demikian pula, penampilan dan gerakan pemain memperluas pembacaan tekstual.

Seperti banyak pakar lain, Kowzan juga sepakat bahwa objek semiotika teater adalah pertunjukannya atau mise-en-scene. Pakar yang lain (mulai dari Souria sampai aliran Greimas) telah mengkaji struktur dasar dari aksi dramatik atau les situations dramatiques, sehingga menggabungkan penelitian teater dengan penelitian tentang struktur naratif. Jika daftar ini diperpanjang, timbul kesan bahwa semiotika teater tak lebih dari sekadar jumlah dari analisis semiotika tentang bentuk lain dari komunikasi (Eco, 1977:108).

Teater merupakan wahana komunikasi yang kompleks karena ia melibatkan hubungan antara para pelakon/pemain dengan khalayak. Proses untuk menghasilkan makna dalam teater tunduk kepada sistem tertentu yang melibatkan gabungan lambang lisan dan bukan lisan. Teater merupakan media yang unidimensional. Setiap unit lambang tidak berdiri dengan sendirinya untuk menggambarkan suatu pesan. Teater harus dilihat sebagai satu gabungan yang menyeluruh dengan lambang-lambang lain dalam konteks tertentu (Bakar, 2006). Tanda-tanda dalam teater bukan tanda dari objek tetapi tanda-tanda dari sebuah tanda tentang sebuah objek. Maksudnya, melampaui denotasinya yang langsung, semua objek, perilaku, dan kata-kata digunakan dalam teater memiliki kekuatan konotatif tambahan. Teori-teori tersebut menjadi landasan konseptual untuk memaknai jenis-jenis tanda yang adalah pertunjukan teater balamut.

\section{A. Tipologi Tanda dan Komunikasi}

Pertunjukan teater balamut episode Bujang Maluala ini berdurasi 2 jam dan terbagi menjadi 17 adegan. Setiap pergantian adegan ditandai dengan fade-out (cahaya meredup dan gelap). Dibuka dengan pembukaan tipikal balamut versi Jamhar. Jamhar dalam panggung ini termasuk salah satu aktor. Ia hadir membuka 
(selama 5 menit) dan menutup pertunjukan (juga sekitar 5 menit). Ceritanya tidak tuntas seperti dalam tradisi lisannya. Episode ini dalam tradisi lisannya berakhir dengan pulangnya Bujang Maluala membawa tiga istri dan menjadi pengganti Kasan Mandi. Sejak itu, Lamut pergi meninggalkan Palinggam karena telah dituduh sebagai orang yang menyembunyikan Saliau Kaca.

\section{Tanda Auditif}

Ketika Jamhar bersila di sudut kiri panggung, cahaya redup disorotkan padanya sementara bagian panggung yang lain masih gelap. Setelah 5 menit berlalu, ia turun diiringi suara suling atau flute dan proyektor dinyalakan menyorotkan potongan-potongan gambar bola dunia, yang bergerak menghadirkan gambar kota Banjarmasin tempo dulu. Perlahan cahanya redup dan gelap, suara flute hilang dan digantikan suara perkusi yang dipukul pelan, lalu lebih cepat, dan sangat cepat. Terdengar suara anak kecil menjerit ketakutan dari kursi penonton. Penonton yang lain tertawa. Sebuah komunikasi terjadi. Dalam panggung ini, tangisan anak kecil. Bagi penonton dewasa, bunyi perkusi adalah tanda auditif yang bersifat ikonik di satu sisi dan simbolik di sisi lain. Keduana konotatif. Namun bagi anak kecil itu, tanda auditif itu sangat denotatif. Pertemuan tanda-tanda auditif itu menimbulkan banyak makna, termasuk makna pertunjukan itu secara keseluruhan. Dalam pertujukan balamut hajat atau pengobatan, tangisan anak kecil sering terdengar karena anak yang akan diobati merasa asing. Namun tangisan anak-anak dalam pertunjukan tradisi lisan itu tak pernah menjadi bahan tertawaan.

Ada empat tanda auditif yang diperhatikan untuk memaknai pertunjukan teater lamut ini, yaitu kata, nada yang muncul dari aktor dan terkait dengan ruang dan waktu, dan musik serta efek suara yang juga terkait dengan waktu.

Kata-kata dikonstruksi dengan fonem-fonem, yakni unit-unit bunyi terkecil yang memungkinkan penutur bahasa mampu membedakan dan mengidentifikasi struktur kata-kata yang sah. Konstruksi fonemik itulah yang mengungkapkan proses signifikasi dasar yang sedang bekerja (Danesi, 2011:115). Dalam aspek ini, teater balamut mengesampingkan pentingnya perwujudan ikonitas tanda-tanda dalam komunikasi verbalnya dalam tradisi balamut Jamhar yang menjadi acuannnya. Cuplikan percakapan antara Raden Kasan Mandi sebagai Raja, Junjung Masari sebagai permaisuri raja, dan Lamut sebagai panglima kerajaan dalam teater Lamut kehilangan nada dan nuansa wayangnya yang sering diasosiasikan sebagai representasi verbal Jawa. Berikut ini sebagian cuplikan percakapan di dalam istana Raja Palinggam.

[00:13:56:04]

Kasan Mandi Junjung Masari Kasan Mandi

Junjung Masari Kasan Mandi

\author{
: Dinda. \\ : Inggih, Kakanda. Ada apa Kakanda? \\ : Saat ini aku sedang dilanda kegalauan yang membuatku risau. Tiap \\ hari aku memikirkannya dan bahkan dalam tidurpun, aku sering \\ memimpikannya. \\ : Kalau Dinda boleh tahu, Kanda, memikirkan siapa maksud Kanda? \\ :Memikiran diriku dan negeri ini. Dinda. Aku, aku sudah terlalu \\ lama untuk memimpin negeri ini. Dan, dan, Kau pun paham betul \\ bagaimana kondisi kesehatanku akhir-akhir ini, Dinda.'
}




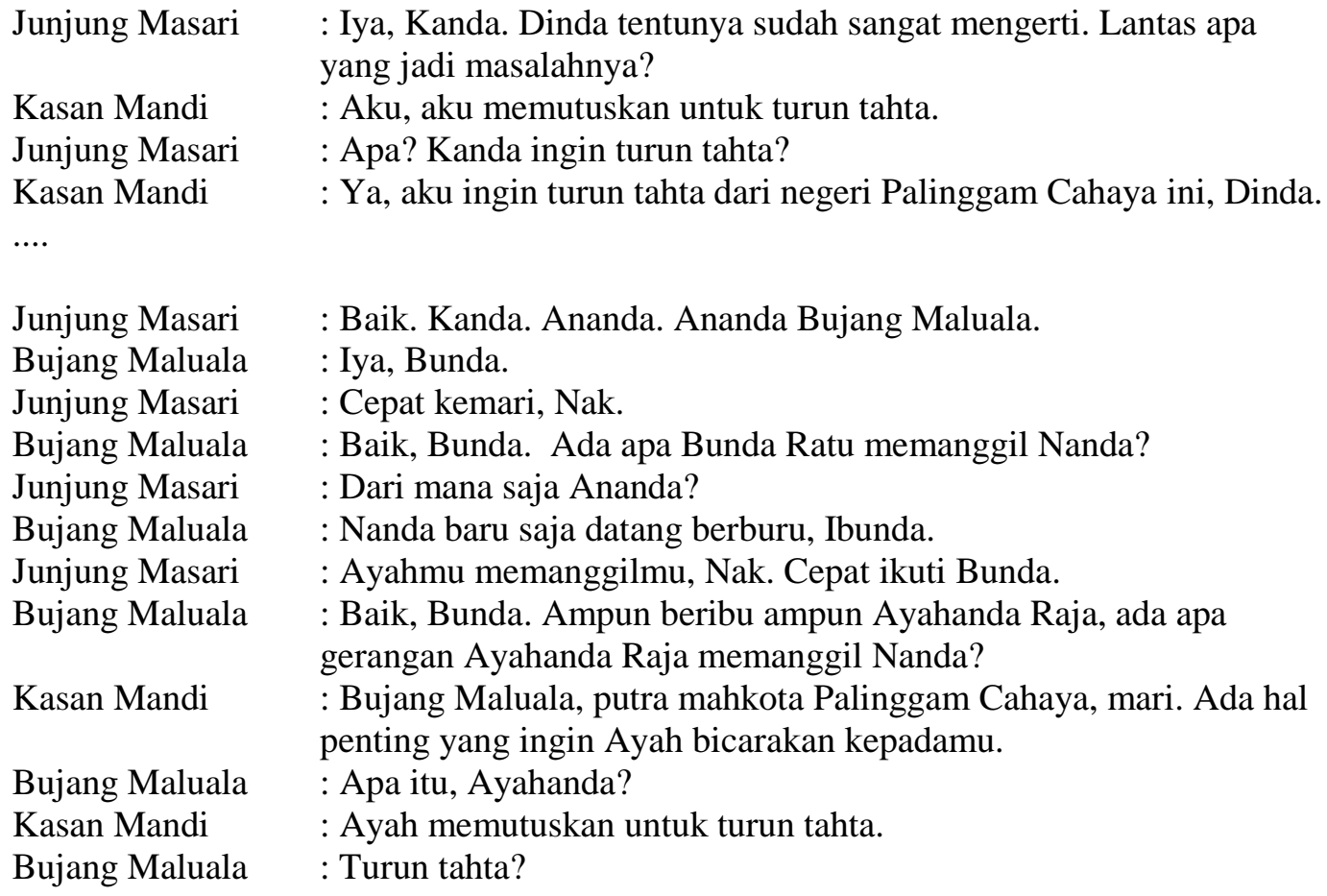
Kasan Mandi $\quad$ : Ayah, sudah lama sekali tidak berjumpa dengannya. Tolong panggilkan dia.
Bujang Maluala : Baik Ayahanda Raja, Nanda mohon pamit untuk mencarikan Paman Lamut. Paman Lamut, uy, Paman Lamut.
Lamut : Ada apa Gusti?
Bujang Maluala : Cepat ke sini, Paman. Ayahanda Raja ingin bicara dengan Paman. Lamut : Inggih pun. Hamba akan segera ke sana. Ampun Gusti, ada apa kiranya Gusti memanggil Hamba ke sini?
Kasan Mandi : Kakang Lamut. Lamut : Inggih pun.
Kasan Mandi : Uma, uma. Lawasnya pian kada kalihatan. Kemana aja Pian? Lamut $\quad$ :Ya am. Ulun ni sibuk mangatam. Lagi musim katam di kampung Ulun bulik. Jadi kaya apa kabar Sampiyan jua?
Kasan Mandi $\quad$ : Ulun sakaluargaan sehat wal afiat, Kang ay.

Kata dan nada sebagai penanda relasi sosial dalam tradisi lisan balamut yang menjadi rujukannya, hilang. Dalam tradisi lisannya, komunikasi verbal antara Kasan Mandi dengan Lamut sangat formal. Lamut memanggilnya dengan sebutan Kanjeng Sinuhun dan Kasan Mandi memanggil Lamut dengan sebutan paman. Nadanya lemah lembut. Bujang Maluala memanggil Kasan Mandi dengan sebutan Rama. Junjung Masari memanggil suaminya dengan sebutan Kakang, sementara Kasan Mandi memanggil Junjung Masari dengan sebutan Ading. Hilangnya tanda-tanda auditif ini dari panggung teater lamut membuat pertunjukan teater ini menjadi pertunjukan baru yang mengingkari seni tradisi yang menjadi acuannya. Pilihan ini bisa dihubungkan dengan atmosfer politik kebudayaan pada era otonomi daerah, yang lebih ingin mendekat ke Melayu daripada ke Jawa. Meskipun demikian, selama sekitar 20 menit, percakapan di 
istana Kasan Mandi itu berlangsung dalam iringan musik gamelan yang sering dipandang sebagai representasi Jawa. Pilihan kata dan nada berperan mengubah ruang dan waktu cerita. Pilihan ini pun tidak koheren dengan pilihan musik pengiringnya. Inkoherensi tanda-tanda auditif yang melekat ada aktor dan di luar aktor ini bisa bermakna ganda: bahwa budaya Banjar yang terbuka bukan amalgamasi sistematis di satu sisi, dan di sisi lain ini bisa berarti ketidakpahaman pada tradisi balamut secara utuh.

Ada dua tanda auditif yang menimbulkan tawa penonton, yaitu alih kode dari bahasa Indonesia normatif dalam tradisi teater modern ke bahasa Banjar sehari-hari (adegan ketiga), dan jeritan anak kecil yang takut dengan hentakan suara perkusi (alam adegan kedua).

$\begin{array}{ll}\text { Bujang Maluala } & \text { Ampun beribu ampun, Ayahanda Raja. Bukan maksud Nanda } \\ & \text { menolak, tapi Nanda belum siap untuk mengemban tugas } \\ & \text { seberat itu. Lagipula ada beberapa hal yang ingin Nanda } \\ & \text { lakukan sebelum nantinya Nanda harus naik tahta. } \\ \text { Kasan Mandi } & \text { Ay, handak baapa ikam, Nak? Handak kawinkah? (penonton } \\ & \text { tertawa) Sambat aja na, biniannya dari mana? Matan } \\ & \text { kerajaan mana? Biar Abah nang mengawini. (penonton } \\ & \text { tertawa) Mengawiniakan. Balum tuntung bapandir. } \\ \text { Bujang Maluala } & \text { : Ay, kada kaya itu pang maksud Ulun. Maksud Nanda, Nanda } \\ & \text { ingin sekali pergi berlayar, merantau, berjelajah ke negeri } \\ & \text { seberang. Belajar banyak dari negeri yang Nanda singgahi, } \\ & \text { agar nantinya dapat bermanfaat bagi diri Nanda dan juga bagi } \\ & \text { negeri kita, Palinggam Cahaya. }\end{array}$

Dalam pertunjukan ini penggunaan bahasa Banjar adalah tanda auditif lebih berhasil menimbulkan tawa penonton daripada bahasa Indonesia.

\section{Tanda Visual pada Aktor}

Dalam klasifikasi tanda Kowzan, ada tiga ekspresi tubuh yang harus diperhatikan dalam menganalisis makna pertunjukan teater, yaitu mimik, gestur, dan gerakan aktor. Ketiganya merupakan bagian dari tanda visual. Tubuh adalah sumber signifikasi yang utama. Mempelajari tanda-tanda yang dihasilkan dengan, melalui, atau pada tubuh adalah salah satu tujuan sentral semiotika. Secara teknis studi atas tanda-tanda ini diberi nama semiotika non-verbal (Danesi, 2011:53). Dalam pelbagai budaya, tanda dan kode tubuh yang mengatur perilaku nonverbal dihasilkan oleh persepsi atas tubuh sebagai sesuatu yang lebih dari sekadar zat fisik. Kedipan mata, isyarat tangan, ekspresi wajah, postur dan tindakan badaniah lainnya mengomunikasikan sesuatu yang relevan dengan budaya dalam situasisituasi sosial tertentu (Danesi, 2011:54).

Tanda-tanda visual dalam teater balamut menjalankan banyak fungsi dan mengirimkan berbagai jenis pesan yang berbeda-beda. Secara sederhana tanda visual dapat didefinisikan sebagai tanda yang dikonstruksi dengan penanda visual yang hanya dapat dilihat bukan didengar, disentuh, dikecap atau dicium. Seperti semua jenis tanda yang lain tanda visual dapat dibentuk secara ikonis, indeksikal dan simbolis (Danesi, 2011:76).

\footnotetext{
${ }^{2}$ Artinya: Apa maumu, Nak? Apa mau kawin? Sebut saja perempuan dari mana? Dari kerajaan mana? Biar yang yang mengawini. Mengawinkanmu maksudnya. Belum selesai bicara.
} 
Karena sumber data ini artikel ini berupa rekaman video amatir yang merekam pertunjukan dengan modus medium shot tanpa close-up, mimik tidak dapat dilihat dengan lebih detail. Oleh karena itu, perhatian lebih difokuskan pada gestur dan gerakan aktor. Gerakan aktor dapat diklasifikasi menjadi beberapa macam: tari, bercanda, bertarung, penghormatan, pemberian hukuman, genit, kepatuhan, kewibaaan, dan kegelisahan, tercengang.

Pakaian sebagai tanda mewakili hal-hal seperti kepribadian, status sosial, dan karakter keseluruhan si pemakai (Danesi, 2011: 205). Pakai dalam pertunjukan ini dapat dikelompokkan menjadi tiga bagian: pakaian palamutan, pakaian orang-orang Palinggam Cahaya, dan pakaian orang-orang dari negeri Cina. Pakaian palamutan berupa setelan baju koko lengan panjang dan celana panjang warna keemasan. Setelan itu dilengkapi dengan kopiah hitam. Pakaian ini kadang-kadang dipakai oleh Jamhar dalam pertunjukan tradisi lisannya.

Pakaian orang Palinggam terbagi menjadi tiga macam: pakaian raja dan istrinya, pakaian putra mahkota raja, dan pakaian para panglima. Pakaian raja dan ratu mirip dengan pakaian raja dalam pertunjukan teater tradisi mamanda dan sinoman hadrah. Raja menggunakan baju warna merah keemasan, celana hitam panjang yang di sisi kanan dan kirinya terdapat tanda garis lurus. Bentuk serupa juga dipakai oleh putra mahkota Bujang Maluala tetapi dengan warna baju dan laung yang berbeda. Raja, putra mahkota, dan Lamut memakai bentuk tutup kepala yang sama, tetapi Labay, Anglung dan Anggasinga memakai jenis pakaian dan tutup kepala yang berbeda meskipun Lamut dan mereka sama-sama sebagai panglima kerajaan. Pakaian ini lebih menegaskan akar kemelayuan dalam kebudayaan Banjar. Nuansa Jawa disertakan pada pakaian Labay, Anglung, Anggasinga, berupa batik. Sementara, pakaian orang Cina berbentuk jubah dengan warna dominan merah, kuning, dan hitam.

Tata rias wajah yang mencolok hanya diberikan kepada empat panglima Palinggam. Make-up tebal putih tersebut membentuk relasi asosiatif dengan wajah para punakawan dalam wayang: Semar, Petruk, Gareng, dan Bagong.

\section{Tanda Visual di Luar Aktor}

Pertunjukan teater ini menggunakan latar hitam. Namun penempelan baliho reklame pertunjukan ini di sayap kanan panggung menjadi unsur tanda baru yang tidak koheren dengan keseluruhan sistem tanda visual pertunjukan ini. Demikian pula dengan properti kapal yang hadir di atas panggung sejak adegan kedua sampai ke-16 menghadirkan tanda ikonis yang bermakna bahwa hampir semua cerita berlangsung di pelabuhan, dan sebagai tanda indeksikal bertentangan dengan jalinan peristiwa dalam tradisi balamut yang menjadi rujukannya.

Pertunjukan balamut hajat versi Jamhar tahun 2011 yang mengisahkan episode Bujang Maluala, menunjukkan adanya beberapa tempat peristiwa penting. ${ }^{3}$ Pertunjukan berlangsung dalam empat sesi. Kisah Bujang Maluala diceritakan di sesi keempat. Kasan Mandi menyerahkan pengasuhan Bujang Maluala kepada Lamut. Kasan Mandi minta Bujang Maluala diajarkan ilmu-ilmu seperti yang telah diajarkan Lamut kepada Kasan Mandi (Hermawan, 2014). Dalam konteks pembukaan episode ini, tarian dua perempuan pembantu kerajaan Cina menjadi tanda visual indeksikal yang mengisyartkan bahwa teater ini akan

\footnotetext{
${ }^{3}$ Pertunjukan dilaksanakan di rumah Asmani, warga kelurahan Sungai Jingah, Banjarmasin pada 29-30 Januari 2011, mulai pukul 20:00 wita sampai 04:30 WITA.
} 
menyimpang dari tradisi rujukannya. Bagaimana Lamut membakar menyan dan bamamang (membaca mantra) untuk mengubah kapal Dandang Aceh Sakti Jaya menjadi kapal Galiung Wangkang dan memasang bendera nelayan bergambar ikan di kapal tersebut juga tidak dijadikan tanda visual.

Pencahayaan menandai perubahan ruang dan waktu serta situasi dramatik. Pembukaan dan penutupan pertunjukan dan pergantian adegan ditandai dengan fade-in (cahaya terang perlahan) dan fade-out (cahaya redup perlahan). Strukturnya mengikuti ruang gerak tokoh. Situasi genting atau kacau ditandai dengan beragam cahaya yang berkelap-kelip cepat. Mimpi divisualkan dengan bayangan pada layar kapal yang ditimbulkan pencahayaan dari belakang panggung. Pencahayaan menjadi bahan tertawaan ketika efek yang akan ditayangkan melalui layar dari proyektor depan tidak berfungsi dengan baik. Di samping itu, efek ombak yang dihasilkan proyektor pada saat aktor berdiri di depan layar.

\section{SIMPULAN}

Tanda-tanda dalam pertunjukan teater Lamut saling terkait antara yang satu dengan yang lain. Makna tanda-tanda visual baru mungkin dipahami secara utuh dengan menyimak tanda-tanda auditif yang menyertainya. Demikian pula dengan makna beberapa tanda-tanda auditif tertentu baru dapat dipahami setelah melihat tanda-tanda visualnya. Dua jalinan tanda yang utama ini tak ada dalam balamut dalam tradisi lisannya. Dalam tradisi lisan balamut hanya ada satu tanda yang dominan: tanda-tanda auditif. Namun bukan hanya karena itu tetapi juka karena teater merupakan kerja kolektif dalam proses produksinya, sementara tradisi lisan balamut adalah tradisi individual.

Jalinan seluruh unsur tanda itu tampak menegaskan bahwa kebudayaan Banjar adalah kebudayaan yang terbuka. Meskipun unsur budaya Jawa yang dominan dalam tradisi lisan balamut dikurangi dalam teater lamut ini, secara visual Jawa dihadirkan secara visual dalam pakaian yang berunsur batik. Panggung ini secara visual dan auditif memperlihatkan adanya dialog budaya antara Melayu, Jawa, dan Banjar.

\section{DAFTAR RUJUKAN}

Aston, Elaine and Savona, George.1991. Theatre as Sign-System: A Semiotics of Text and Performance. London and New York: Routledge.

Bakar, Abdul Latiff Abu. 2006. Aplikasi Teori Semiotika dalam Seni Pertunjukan dalam Etnomusikologi, Vol.2 No. 1, Mei 2006: 45-51.

Bakhtiar Sanderta dan M. Thaha, 2000. Pantun, Madihin, Lamut. Banjarmasin; Dinas Pendidikan dan Kebudayaan dan Dewan Kesenian Kalimantan Selatan.

Danesi, Marcel. 2011. Pesan, Tanda, dan Makna: Buku Teks Dasar mengenai Semiotika dan Teori Komunikasi. Cetakan II. Terjemahan Evi Setyarini dan Lusi Piantari. Yogyakarta: Jalasutra. 
Eco, Umberto. 1977. "Semiotics of Theatrical Performance." dalam The Drama Review: TDR, Vol. 21, No. 1, Theatre and Social Action Issue (Mar., 1977), pp. 107-117. Diakses melalui The MIT Press (http://www.jstor.org/stable/1145112. Diakses: 06/04/2013 16:50.

Hermawan, Sainul. 2014. "Tafsir Pop Balamut 99 Juta” dalam Media Kalimantan, 27 April. Versi online di: http://mediakalimantan.com/artikel-805-tafsirpop-balamut-99-juta.html (akses 29/5/2014).

Ideham, M. Suriansyah, dkk. 2005. Urang Banjar dan Kebudayaannya. Cetakan Pertama. Banjarmasin: Badan Penelitian dan Pengembangan Daerah Propinsi Kalimantan Selatan.

Jarkasi, Djantera Kawi, dan Zainuddin Hanafi. 1997. Struktur Sastra Lisan Lamut. Jakarta: Pusat Pembinaan dan Pengembangan Bahasa, Departemen Pendidikan dan Kebudayaan.

Karno, Rudi (Sutradara). 2014. Balamut Lakon Bujang Maluala. Video pribadi. 120 menit.

M. Suriansyah Ideham, dkk. (Eds.). 2003. Sejarah Banjar. Banjarmasin: Pemerintah Kalimantan Selatan.

M. Syafullah. 2008. "Penjaga Identitas Kesenian Rakyat Banjar" dalam Kompas, 8 September.

Marsman Hatuwe. 1999. "Seni Tradisional Masyarakat Banjar dan Permasalahannya di Kalimantan Timur" artikel dalam seminar "Seni Pertunjukan Global, Globalisasi Seni Pertunjukan, Tirtagangga Karangasem, Bali, 10-13 September 1999.

Mukhlis Maman. 2011. Lamut. Banjarbaru: Scripta Cendekia.

Pavis, Patrice. 1978. "The Semiotics of Theatre" dalam Versus No. 21. Terjemahan Tjaaart Potgieter.

Sabhan dan Suwarno Muriyat. 2011. Lamut dan Karungut: Seni Pertunjukan Tradisi Lisan Kalimantan. Banjarbaru: Scripta Cendekia.

Sauter, Willmar. 1947. The Theatrical Event: Dynamics of Performance and Perception. Iowa City: University of Iowa Press.

Yusran, Mohammad dkk. 2004. Peta Kesenian Kalimantan Selatan. Banjarmasin: Taman Budaya Kalimantan Selatan. 